\title{
Evaluation of Bacterial Antagonists for Biological Control of Broccoli Head Rot Caused by Pseudomonas fluorescens
}

\author{
Xiaohui Cui and Rob Harling
}

Scottish Agricultural College, West Mains Road, Edinburgh EH9 3JG, Scotland, UK. Accepted for publication 15 December 2005.

\begin{abstract}
Cui, X., and Harling, R. 2006. Evaluation of bacterial antagonists for biological control of broccoli head rot caused by Pseudomonas fluorescens. Phytopathology 96:408-416.

Pectolytic strains of Pseudomonas fluorescens are opportunistic pathogens of broccoli, causing head rot in temperate regions of the world. In this study, we investigated the potential of two bacterial isolates, P. fluorescens m6418 and Bacillus sp. A24, for biological control of broccoli head rot caused by $P$. fluorescens 5064, isolated from diseased broccoli in Scotland, UK. P. fluorescens $\mathrm{m} 6418$, a Tn5 mutant of wildtype 5064, is nonpathogenic and overproduces an extracellular metabolite with strong antimicrobial activity. In this study, we identified the anti-

microbial metabolite produced by strain $\mathrm{m} 6418$ as pyrrolnitrin. $P$. fluorescens $\mathrm{m} 6418$ had significant inhibitory effects against strain 5064 both in culture and on broccoli leaves. In an excised broccoli head pathogenicity test, strain m6418, when coinoculated with $P$. fluorescens 5064, reduced disease by $41 \%$. Bacillus sp. A24 produces an enzyme that can degrade $\mathrm{N}$-acyl homoserine lactones, signaling molecules employed by bacteria for quorum sensing. Bacillus sp. A24 was capable of out-competing $P$. fluorescens 5064 when grown together in culture, and could degrade the quorum sensing signal of $P$. fluorescens 5064 (and thereby attenuate its virulence gene production). However, Bacillus sp. A24 had only a limited biocontrol effect on P. fluorescens 5064 in the excised broccoli head assay.
\end{abstract}

Broccoli (Brassica oleracea L. var. italica Plenck) head rot is a serious disease in broccoli production regions of Australia, Canada, the United States, Ireland, and the United Kingdom $(6,25,38,51)$. Disease losses may occur from 30 to $100 \%$ in some fields in the United States (26). In the United Kingdom, crop losses of $29 \%$ average have been quantified in a wet year, resulting in a $\$ 20 \mathrm{M}$ loss to the industry (23). This opportunistic bacterial disease is caused by Pseudomonas fluorescens GpIV (pectolytic $P$. fluorescens, sometimes referred to as $P$. marginalis) and Erwinia carotovora (currently Pectobacterium carotovorum), the former being the most frequently isolated $(3,6,7,25,26,37$, $42,51)$. There are very few bactericidal chemicals available for controlling this disease-most are copper formulations with limited effectiveness; therefore, alternative strategies such as biological control are desirable.

Pathogenic $P$. fluorescens produces biosurfactant that has been reported to play a major role in virulence (26). In a previous study, we have provided evidence that $P$. fluorescens 5064, a pathogenic broccoli isolate from the United Kingdom, regulates its biosurfactant production through quorum sensing (11).

In previous work in our laboratory, a library of wild-type $P$. fluorescens 5064 mutants deficient in biosurfactant production was generated by $\operatorname{Tn} 5$ mutagenesis (12). One of these mutants, m6418, overproduced a substance with strong antibiotic properties against wild-type P. fluorescens 5064 and Escherichia coli (unpublished data). Both Pseudomonas and Bacillus groups have drawn considerable attention as biological control agents since they are widely occurring, many nonpathogenic species are available, and they are highly effective at eliminating competing microbes $(2,5,32,45,46,50)$. The antibiotic-producing strain m6418,

Corresponding author: R. Harling; E-mail address: rob.harling@ @ac.ac.uk

DOI: 10.1094/PHYTO-96-0408

(c) 2006 The American Phytopathological Society which has lost its pathogenicity, and the quorum sensing signal (QSS) degrading strain Bacillus sp. A24 might have potential as biocontrol agents.

P. fluorescens has been reported to produce a diverse array of antibiotics, which are largely responsible for the biocontrol effectiveness of this bacterium. The important antimicrobial metabolites are phenazines (Phz) (49), pyrrolnitrin (Prn) $(27,41)$, pyoluteorin (Plt) (28), and 2,4-diacetylphloroglucinol (Phl) $(40,48)$.

Quorum sensing is a bacterial communication system by which bacteria control the expression of certain genes in response to their population density via a small signal molecule, the QSS, the most widespread of which in gram-negative bacteria are the $N$ acyl homoserine lactones (AHLs) (20). Since many plant-pathogenic bacteria employ quorum sensing to control their virulence factor production, quorum sensing has become an attractive target for antimicrobial therapy $(10,19)$. Dong et al. (16) discovered an enzyme from Bacillus sp. 240B1 that was capable of degrading the QSS of E. carotovora, thereby blocking its quorum sensing system and reducing virulence. Later studies discovered that this QSS degrading enzyme, designated as AiiA, and its homologues are widespread in many subspecies of Bacillus $(15,35)$. Expression of aiiA in the transformed E. carotovora strain SCG, a pathogen that causes soft rot disease in many plants, significantly reduces release of QSS, decreases extracellular pectolytic enzyme activities, and attenuates pathogenicity in potato, eggplant, Chinese cabbage, carrot, celery, cauliflower, and tobacco (16). In a recent study, Dong et al. (17) discovered that B. thuringiensis, when coincubated with E. carotovora, abolished its accumulation of AHL signal and significantly decreased the symptom development of potato soft rot caused by this pathogen.

The objectives of this study were to (i) identify and assay the antibiotic substance produced by $P$. fluorescens m6418; (ii) determine if Bacillus sp. A24 is capable of degrading the QSS, acylhydroxyoctanoyl-homoserine lactone, produced by the pathogenic $P$. fluorescens 5064; and (iii) evaluate P. fluorescens m6418 and Bacillus sp. A24 for their abilities to antagonize the pathogen P. fluorescens 5064 and control broccoli head rot disease. 


\section{MATERIALS AND METHODS}

Bacterial strains and growth conditions. Wild-type $P$. fluorescens 5064, isolated at Scottish Agricultural College from infected broccoli collected in SE Scotland (42), was grown at $26^{\circ} \mathrm{C}$ in Luria-Bertani (LB) medium. Mutant strain m6418 (derived from $P$. fluorescens 5064 by Tn5 mutagenesis [12]) was grown at $26^{\circ} \mathrm{C}$ in LB medium with kanamycin $(50 \mathrm{mg} / \mathrm{liter})$. Pythium ultimum was maintained, and the antifungal assay was carried out on potato dextrose agar (PDA) plates at $28^{\circ} \mathrm{C}$. A spontaneous rifampicin-resistant $\left(\mathrm{Rif}^{\mathrm{r}}\right)$ derivative of $P$. fluorescens 5064 was selected to facilitate monitoring the cell numbers of coinoculated bacteria in the pathogenicity tests. It was grown in LB medium with rifampicin (50 mg/liter). The AHL-degrading strain Bacillus sp. A24 was provided by G. Defago (ETH, Zurich, Switzerland). This bacterium was grown in LB medium at $30^{\circ} \mathrm{C}$. The biosensor strain used in this study to detect QSS was E. coli (pSB401), which was provided by P. Williams (Nottingham University, UK). It was grown in $\mathrm{LB}$ medium at $37^{\circ} \mathrm{C}$ with tetracycline (20 mg/liter).

Antibiotic extraction. Cell-free supernatants from $P$. fluorescens strains 5064 (as negative control) and m6418 were prepared from 1 liter of $\mathrm{LB}$ broth grown at $26^{\circ} \mathrm{C}$ for 50 to $55 \mathrm{~h}$ (optical density $=2.1$ at $500 \mathrm{~nm}$ ). The supernatants were extracted twice with equal volumes of dichloromethane. The dichloromethane organic phases were combined and taken to dryness by rotary vacuum evaporation at $37^{\circ} \mathrm{C}$. The resulting residue was redissolved in $1 \mathrm{ml}$ of methanol (at a concentration of $\times 1,000$ higher than that in the original culture) and sterilized with a $0.22 \mu \mathrm{l}$ filter (Millex-GS, Millipore Co., Billerica, MA).

Thin layer chromatography. Twenty microliters of each antibiotic extract was spotted onto thin-layer plates coated with Silica Gel $60 \mathrm{~F}_{254}$ (E. Merck, AG, Darmstadt, Germany). The plates were developed in chloroform/acetone (9:1, vol/vol). The developed plates were visualized under long- and short-wave UV light and then sprayed with Pauly's reagent (diazotized sulfanilic acid in which $5 \%$ sodium hydroxide in $50 \%$ ethanol is used as the base) or with Ehrlich's reagent (1\% p-dimethyl aminobenzaldehyde in HCI followed by $0.1 \%$ sodium nitrite in water). Two-dimensional thin layer chromatography (TLC) was performed for the plates used for antibiotic preparation. The plates were developed in chloroform/acetone $(9: 1, \mathrm{vol} / \mathrm{vol})$ first, turned through an angle of $90^{\circ}$, and placed into the second solvent: toluene/acetone $(4: 1$, vol/vol). The developed plates were observed under UV light to detect fluorescing and adsorbing bands. Bands and blank areas were scraped separately from the plates and eluted with $40 \mu \mathrm{l}$ of chloroform. The eluates were kept at $4^{\circ} \mathrm{C}$ for the antifungal assay. TLC of antibiotic extracts was performed three times, largely to obtain satisfactory images for photography.

Antifungal assay. An 8-mm-diameter hole was punched, using a sterile pipette tip, in the center of a PDA plate and filled with a pre-prepared sterile-water suspension of oospores (at a concentration of $10^{6}$ oospores per $\mathrm{ml}$ ) of Pythium ultimum. A small piece of filter paper (Whatman International Ltd., Maidstone, Kent, England), which had been dipped to saturation into the eluted antibiotic solution (produced by $P$. fluorescens m6418), was placed on the plate about 2 or $3 \mathrm{~cm}$ from the middle hole. Another piece of filter paper, which had been dipped into the solvent (chloroform), was placed on the other side of the hole and served as the control. The plate was incubated upright at $28^{\circ} \mathrm{C}$ for 2 days before the inhibitory effect could be observed. The antifungal assay was performed three times.

QSS degradation assay. Bacillus sp. A24 was coinoculated with P. fluorescens 5064 in $300 \mathrm{ml}$ of LB broth at the same time, $6 \mathrm{~h}$ earlier or $6 \mathrm{~h}$ later. The bacterial mixtures were grown for $48 \mathrm{~h}$ before proceeding to the following QSS extraction. Cell-free supernatants were prepared from the above bacterial mixtures and extracted twice with equal volumes of dichloromethane. The di- chloromethane organic phases were combined and taken to dryness by rotary vacuum evaporation at $37^{\circ} \mathrm{C}$. The resulting residue (QSS extract) was redissolved in $50 \mu \mathrm{l}$ of $95 \%$ ethanol for further AHL bioassay. The AHL bioassay was carried out with biosensor E. coli (pSB401) that responds to exogenous QSS by emitting bioluminescence (11). Five milliliters of prewarmed semi-LB agar $(0.5 \%, \mathrm{wt} / \mathrm{vol})$, heated in a microwave until melted and then cooled to about $50^{\circ} \mathrm{C}$, was seeded with $50 \mu \mathrm{l}$ of bacterial biosensor from an overnight LB culture. In addition, $50 \mu \mathrm{l}$ of QSS extract was added. The mixture was mixed well and immediately overlaid on the surface of a $35-\mathrm{mm}$ petri dish containing LB agar. The plate was incubated at $37^{\circ} \mathrm{C}$ in an upright position for $4 \mathrm{~h}$ and the induced luminescence was visualized with a ChemiImager 4400 camera (Alpha Innotech Corporation, San Leandro, CA).

Quantification of viable bacterial cell number. Two microliters of each sample to be quantified was diluted in a series of 10fold dilutions with sterile distilled water and $50 \mu$ of each diluted bacterial solution was spread on LB plates with the appropriate antibiotic. Plates were then incubated at $30^{\circ} \mathrm{C}$ for 2 days to allow colonies to develop, which were then counted at suitable dilutions (using three replicates).

Effects of mutant strain m6418 on P. fluorescens 5064 growth in culture. Strain m6418 was cocultured with $P$. fluorescens $5064 \mathrm{Rif}^{\mathrm{r}}$ at the same time, $6 \mathrm{~h}$ earlier or $6 \mathrm{~h}$ later. The bacterial mixtures were incubated at $30^{\circ} \mathrm{C}$. Six hours after the incubation and then every few hours after that, samples were taken for the quantification of viable bacterial cell number (as described previously). These experiments were performed twice.

Population dynamics of $\mathbf{m 6 4 1 8}$ and $P$. fluorescens 5064 when coinoculated onto broccoli seedlings. Broccoli seeds (cv. Skiff FI) were sown into five separate pots ( 25 seeds per 10 by $18 \mathrm{~cm}$ pot) to germinate. After 4 weeks, when enough true leaves were present, 25 true leaves in each pot were selected and marked to distinguish them from leaves appearing later as the plants grew. The marked leaves were sprayed evenly with bacterial suspensions according to different treatments. One treatment was applied per pot. The bacterial concentrations used for both bacteria were $1 \times 10^{8} \mathrm{CFU} / \mathrm{ml}$. $P$. fluorescens $\mathrm{m} 6418$ was sprayed at the same time, 1 day earlier or 1 day later than P. fluorescens 5064 Rif $^{\mathrm{r}}$. Strain m6418 and P. fluorescens $5064 \mathrm{Rif}^{\mathrm{r}}$ also were sprayed alone on the seedlings as controls. The seedlings were placed in a Fisons environmental cabinet (Fisher Scientific UK Ltd., Loughborough, England - formerly Fisons Ltd.) with a 16-h photoperiod and high humidity $(100 \%)$ at $20^{\circ} \mathrm{C}$ (day) $/ 10^{\circ} \mathrm{C}$ (night). The marked leaves were removed on the first, second, fourth, eighth, and sixteenth day after inoculation, weighed, and placed into sterile tubes containing $10 \mathrm{ml}$ of sterile distilled water. The tubes were sonicated at $40 \mathrm{KHz}$ in a water bath sonicator (Decon FS200, Decon Laboratories Ltd., Hove, East Sussex, England) for $7 \mathrm{~min}$ to remove the bacteria from the leaf surfaces and to distribute the cells evenly in the suspensions. The bacterial suspensions were serially diluted in sterile distilled water. A $100-\mu \mathrm{l}$ aliquot of each dilution was plated onto appropriate LB plates (i.e., P. fluorescens 5064 onto LB plates with rifampicin; m6418 onto LB plates with kanamycin; coinoculated samples were spread onto both kinds of plates, simultaneously). All the plates were incubated at $30^{\circ} \mathrm{C}$ for $48 \mathrm{~h}$ to allow the total number of colonies to be recorded. The number of bacterial cells was related to the fresh weight of the leaf from which they were collected. Five replications were made for each treatment at each sampling time. This experiment was performed twice although only one data set was obtained due to growth cabinet failure in the first attempt.

Excised broccoli head pathogenicity test. The excised broccoli head pathogenicity test procedure was the same as described by Darling et al. (13). Mature broccoli heads (purchased from a supermarket) were inoculated by placing two pieces $(2 \times 2 \mathrm{~cm})$ of cotton lint on the head (one upon the other), which had been soaked in a suspension of bacteria. Heads were kept upright with 
sponge collars in closed Magenta GA7 vessels (Sigma Chemicals, Poole, Dorset, England) with $20 \mathrm{ml}$ of sterile distilled water to maintain humidity. Heads were incubated for 5 days at $20^{\circ} \mathrm{C}$ (day) $/ 10^{\circ} \mathrm{C}$ (night) with a 16 -h photoperiod in a Fisons environmental cabinet. Four treatments were applied, namely coinoculation with strain m6418 and wild-type $P$. fluorescens 5064, P. fluorescens 5064 alone, strain m6418 alone, and a water control. The coinoculum ratio of strain m6418 to P. fluorescens 5064 was 1:1 and the final concentration of each strain was $1 \times 10^{8} \mathrm{CFU} / \mathrm{ml}$. For Bacillus sp. A24, six treatments were applied, including different inoculum ratios of Bacillus sp. A24 and P. fluorescens 5064, i.e., ratios of $\mathrm{A} 24 / 5064$ of $1: 0,1: 3,1: 1,3: 1$, and $0: 1$ plus a water control. The concentration for each bacterium (strain m6418 and Bacillus sp. A24) was $1 \times 10^{8} \mathrm{CFU} / \mathrm{ml}$ and the experiments were performed again with a concentration of $1 \times 10^{6} \mathrm{CFU} / \mathrm{ml}$ for each strain. Ten replicates were performed for each treatment and the experiment was repeated twice. A five point scoring scale was used to assess the severity of disease symptoms (13): $0=$ no symptoms, 1 = water soaking (loss of waxy bloom from florets), 2 = water soaking and tissue browning but no rot, $3=$ tissue browning and softening (with rot), and $4=$ extensive black soft rot. Data were subjected to percentile angular transformation using arcsine (44) before analysis; thus, the above categories 0 to 4 became $0(=0), 33(=1), 50(=2), 67(=3)$, and $100 \%(=4)$, respectively. Statistical analysis, i.e., analysis of variance and
Fisher's protected least significant difference test, were conducted using Genstat 5 (Rothamsted Experimental Station, Rothamsted, England).

\section{RESULTS}

Identification of antibiotics produced by strain m6418. The antibiotic extracts from strain m6418 and wild-type $P$. fluorescens 5064 were separated by TLC in chloroform/acetone (9:1, vol/vol). With strain m6418, a dark spot, corresponding to an Rf of 0.48 was observed under short-wave UV light. This spot, which could not be visualized under long-wave UV light, was impressively large compared with the other spots on the plate, reflecting a large amount of the compound. The corresponding spot was not present in the wild-type sample. As Prn typically shows a dark nonfluorescent spot under short-wave UV light and was reported to have an $\mathrm{Rf}$ value of 0.48 under the chromatographic conditions used in this study (4), we tentatively identified the antibiotic produced by strain m6418 as Prn. The color reaction results were further consistent with this conclusion. The antibiotic spot turned orange with Pauly's reagent and red with Erhlich's reagent (Fig. 1), indicating the presence of phenolic and pyrrolic forms $(1,39,47)$.

A bioassay using Pythium ultimum was performed to identify antibiotic activity of the Prn spot produced by strain m6418. Pythium ultimum is a fast-growing fungus, and after 2 days,
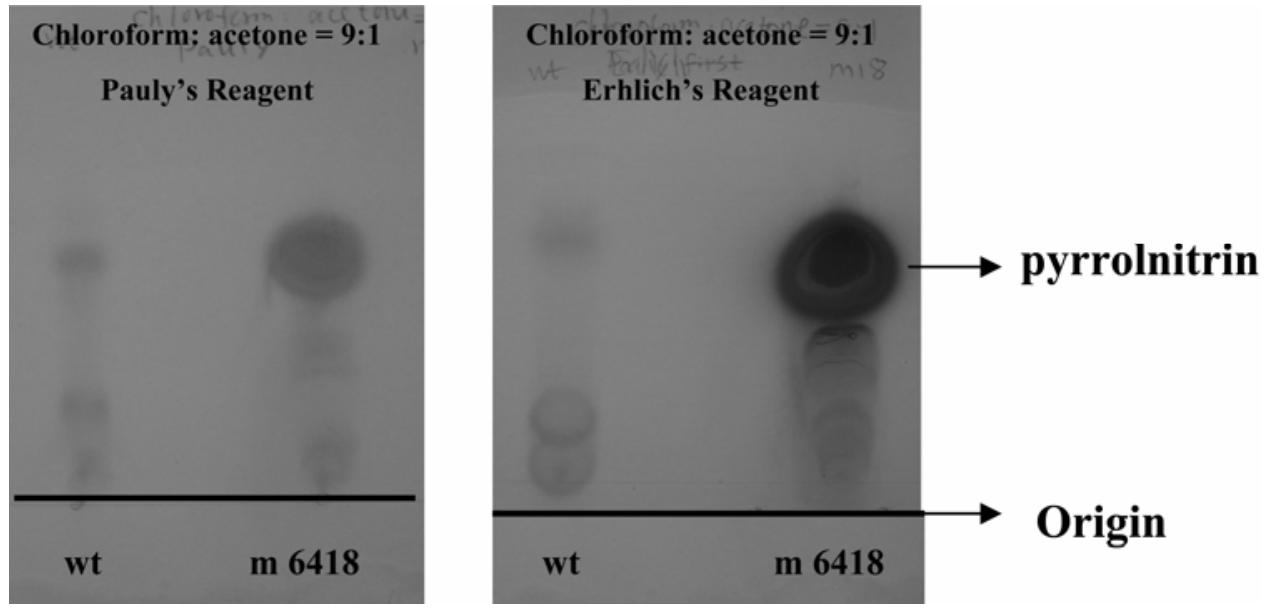

Fig. 1. Detection of pyrrolnitrin on thin layer chromatography plates. wt $=$ Pseudomonas fluorescens 5064, pathogenic to broccoli; $6418=$ P. fluorescens 5064 mutant 6418, nonpathogenic to broccoli. The pyrrolnitrin spot turned orange with Pauly's reagent (left) and red with Erhlich's reagent (right).

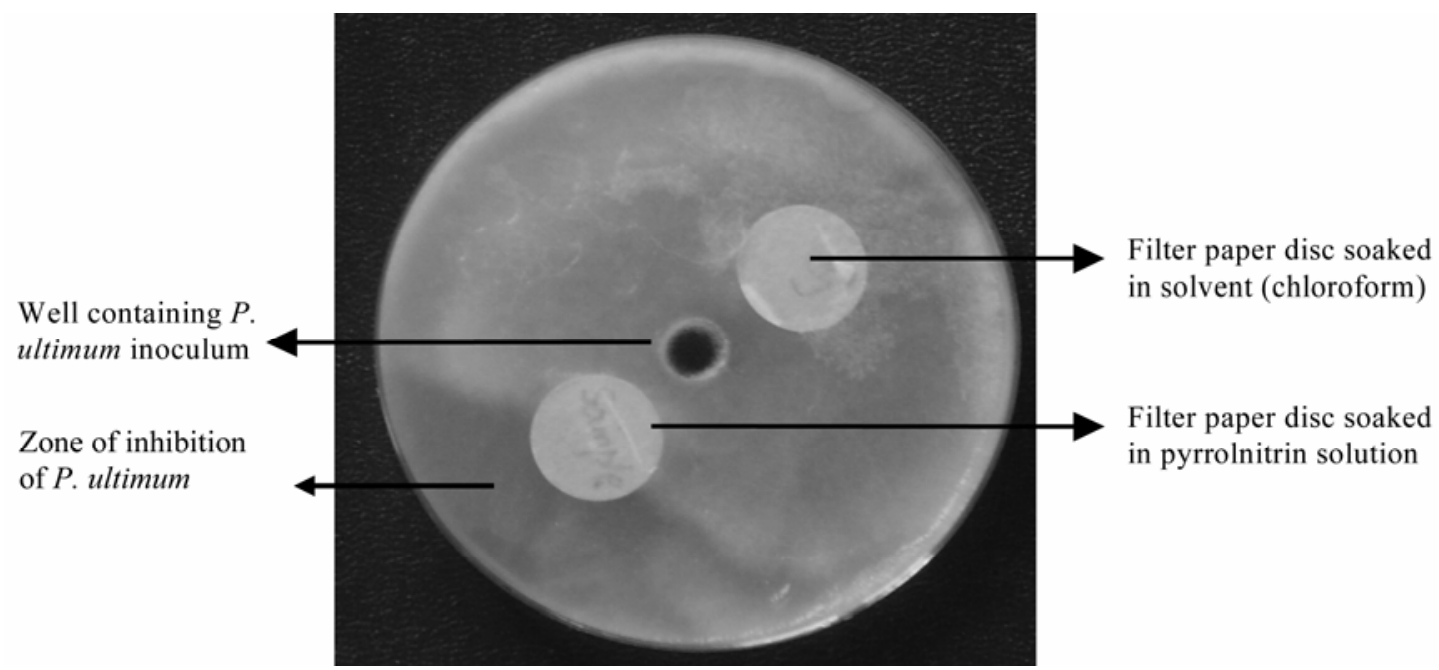

Fig. 2. Agar plate bioassay of pyrrolnitrin, produced by Pseudomonas fluorescens m6418, against Pythium ultimum. Note the zone of inhibition around the pyrrolnitrin disk is not uniform because of overgrowth by this fast-growing pathogen from the control (solvent) disk. 
colony growth was inhibited on the side of the agar plates containing the Prn filter paper disk (Fig. 2).

The TLC profile also enabled detection of other antibiotics such as Phl, Plt, and Phz in strain m6418 and wild-type P. fluorescens 5064 (Table 1). In addition to the major antibiotic Prn, strain m6418 also produced $\mathrm{Phl}$, which was visible under longwave UV light (blue fluorescence) with an $\mathrm{Rf}$ value of 0.41 (toluene/acetone, 4:1) (31). In contrast to strain m6418, wild-type $P$. fluorescens 5064 did not produce any detectable antibiotics listed above. Although a color spot also appeared at Rf 0.48 in the wild-type $P$. fluorescens 5064 chromatograms (Fig. 1), this spot, under short-wave UV light, had blue fluorescence instead of the dark nonfluorescent dot corresponding to Prn in the chromatogram for strain m6418; therefore, we concluded this was not Prn.

Degradation of P. fluorescens 5064 QSS by Bacillus sp. A24. Biosensor E. coli (pSB401) produces luminescence in response to the presence of AHL produced by $P$. fluorescens 5064, as we showed in a previous study (11). No visible luminescence was observed when either Bacillus sp. A24 was inoculated in the medium before strain 5064 or when they were coinoculated (Fig. 3 ). The Bacillus sp. A24 thus has a strong ability to degrade the QSS produced by $P$. fluorescens 5064. When P. fluorescens 5064 was incubated $6 \mathrm{~h}$ before Bacillus, a faint but visible luminescence occurred (Fig. 3). This indicated that, although inoculated 6 h later than P. fluorescens 5064, Bacillus sp. A24 could still grow well and destroy most, but not all, of the QSS produced by P. fluorescens 5064.

Effects of Bacillus sp. A24 on growth of P. fluorescens 5064 in culture. When P. fluorescens 5064 and Bacillus sp. A24 were coinoculated simultaneously, the final cell number ratio of $P$. fluorescens to Bacillus, after 2 days incubation, was 1:25 (actual culturable cell numbers were $5.0 \times 10^{5}: 1.2 \times 10^{7}, P$. fluorescens
5064/Bacillus sp. A24). Even when inoculated 6 h later than P. fluorescens 5064, Bacillus sp. A24 could still grow well and showed a ratio of $P$. fluorescens to Bacillus of 1:1.2 (culturable cell numbers were $9.0 \times 10^{5}: 1.1 \times 10^{6}$, respectively). If Bacillus sp. A24 was inoculated $6 \mathrm{~h}$ earlier than P. fluorescens, then no $P$. fluorescens could be detected in the culture (cell numbers 0:8.0 $\times$ $10^{8}$, P. fluorescens/Bacillus). Based on these results, Bacillus sp. A24 could out-compete $P$. fluorescens 5064.

Effects of strain m6418 on $P$. fluorescens 5064 growth in culture. Strain m6418 significantly inhibited the growth of $P$. fluorescens 5064 in liquid culture (Figs. 4 and 5). The greatest inhibitory effect resulted when strain m6418 was inoculated $6 \mathrm{~h}$ before $P$. fluorescens 5064, when the P. fluorescens 5064 cell number was five times less than when grown alone (Fig. 4). In the reciprocal experiment where the effect of $P$. fluorescens 5064 on growth of strain m6418 was examined, the m6418 population initially remained low when inoculated $6 \mathrm{~h}$ later than wild-type 5064, but it increased quickly after $20 \mathrm{~h}$ coincubation (Fig. 5). In contrast, the 5064 population remained at a low level throughout the experiment when inoculated $6 \mathrm{~h}$ later than strain m6418 (Fig. 4).

Population dynamics of strain $\mathrm{m} 6418$ and $P$. fluorescens 5064 when coinoculated on broccoli seedlings. When inoculated 1 day later than the wild type, strain m6418 reduced the growth rate of the wild type, but not when inoculated 1 day before it (Fig. 6). When strains 5064 and m6418 were coinoculated simultaneously, m6418 inhibited 5064 growth on the first and second day; however, the inhibitory effect was eliminated after that (Fig. 6). Strain m6418 showed less fitness on the leaf surface compared with 5064 , indicated by the faster decline in the population of m6418 (Figs. 6 and 7). These observations were derived from an unrepeated experiment.

TABLE 1. Antibiotics produced by wild-type Pseudomonas fluorescens 5064 and P. fluorescens m6418 as detected by thin layer chromatography (TLC)

\begin{tabular}{|c|c|c|c|}
\hline \multirow[b]{2}{*}{ Antibiotics } & \multirow[b]{2}{*}{ Identity on TLC } & \multicolumn{2}{|c|}{ Presence in } \\
\hline & & m6418 & Wild type \\
\hline 2,4-Diacetyl-phloroglucinol (Phl) & $\begin{array}{l}\mathrm{Rf}=0.41 \text { (toluene-acetone }=4: 1) \\
\text { Fluorescence under long-wave UV light }\end{array}$ & Yes & No \\
\hline Pyoluteorin (Plt) & $\begin{array}{l}\mathrm{Rf}=0.27 \text { (chloroform-acetone }=9: 1) \\
\mathrm{Rf}=0.31 \text { (toluene-acetone }=4: 1 \text { ) } \\
\text { Fluorescence under short-wave UV light }\end{array}$ & No & No \\
\hline Pyrrolnitrin (Prn) & $\begin{array}{l}\mathrm{Rf}=0.48 \text { (chloroform-acetone }=9: 1) \\
\mathrm{Rf}=0.53 \text { (toluene-acetone }=4: 1) \\
\text { Dark dot under short-wave UV light } \\
\text { Pauly's reagent (red or orange color) } \\
\text { Ehrlich's reagent (red color) }\end{array}$ & Yes & No \\
\hline Phenazine $(\mathrm{Phz})$ & Colony pigmentation (dark zone surrounding colonies on agar) & No & No \\
\hline
\end{tabular}
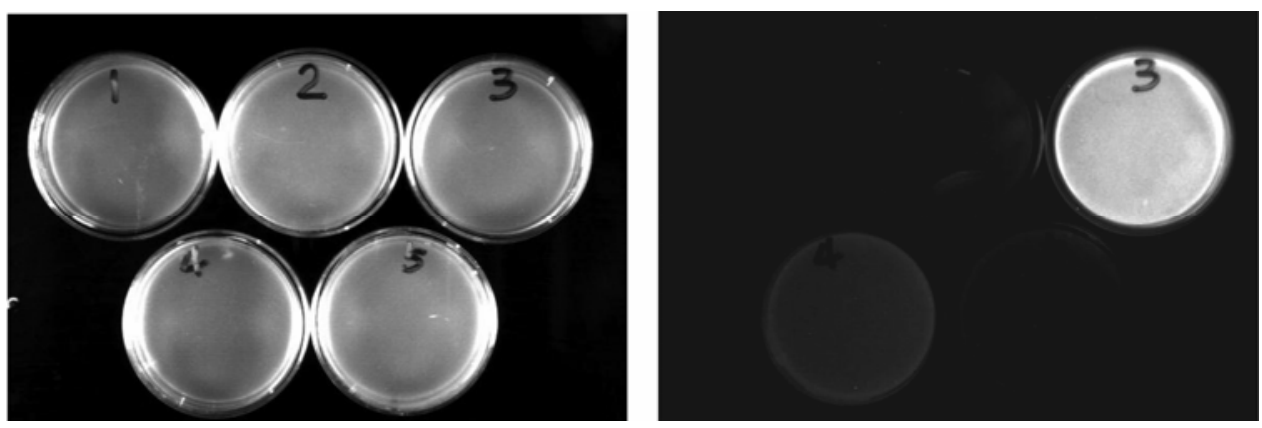

Fig. 3. Quorum sensing signal degradation in Pseudomonas fluorescens 5064 by Bacillus sp. A24. Quorum sensing signal (N-3-hydroxyoctanoyl-homoserine lactone [11]) was extracted from culture filtrates of different bacterial co-inoculation mixtures after $48 \mathrm{~h}$, added to semi-Luria-Bertani (LB) agar seeded with biosensor Escherichia coli (pSB401), and overlaid on LB agar plates. The biosensor produces light in the presence of quorum sensing signal. Left: photographed in white light. Right: photographed in darkness. Treatments were as follows: 1, negative control (biosensor E. coli [pSB 401] only); 2, co-inoculation of Bacillus sp. A24 and P. fluorescens 5064 at the same time; 3, positive control (P. fluorescens 5064); 4, P. fluorescens 5064 inoculated $6 \mathrm{~h}$ earlier than Bacillus sp. A24 (faint luminescence); and 5, Bacillus sp. A24 inoculated $6 \mathrm{~h}$ earlier than P. fluorescens 5064. 
Biocontrol efficacy of Bacillus sp. A24 and P. fluorescens strain $\mathbf{m 6 4 1 8}$ in excised broccoli head pathogenicity tests. Inoculation of broccoli heads with pathogenic P. fluorescens 5064 resulted in $80 \%$ disease after 5 days with extensive black soft rot (Fig. 8). Simultaneous coinoculation of the pathogen with the nonpathogenic mutant m6418 reduced disease to $47 \% \quad(=41 \%$ reduction); tissue was brown but not soft-rotted. Heads inoculated with water alone had a disease score of $20 \%$ (heads were slightly darkened and showed a loss of the waxy bloom), which is normal for negative controls. Heads inoculated with strain m6418 had virtually no symptoms at all $(3 \%)$. This suggested that some of the darkening of the water control treatment may have been due to residual nonpathogenic bacterial activity beneath the water-soaked cotton lints and this activity was abolished by the biocontrol activ- ity of the mutant. The achieved level of significance in the $F$ test prior to performing Fisher's protected LSD test was $P=0.0382$.

To test the biocontrol activity of Bacillus sp. A24, we coinoculated it with the pathogen at different ratios of Bacillus to $P$. fluorescens 5064 and at two different final inoculum concentrations (Fig. 9). When the pathogen was inoculated at a rate of $1 \times 10^{8} \mathrm{CFU} / \mathrm{ml}$, the Bacillus was ineffective, but at a rate of $1 \times$ $10^{6}$, the Bacillus gave a disease reduction of $26 \%$. The Bacillus itself, when inoculated alone, induced greater disease symptoms (tissue darkening) compared with that of the water control, although these differences were not significant. The achieved levels of significance in the $F$ tests for these experiments prior to performing Fisher's protected LSD test were $P=0.0325$ and 0.0296 for the $\log 6$ and $\log 8 \mathrm{CFU} / \mathrm{ml}$ tests, respectively.

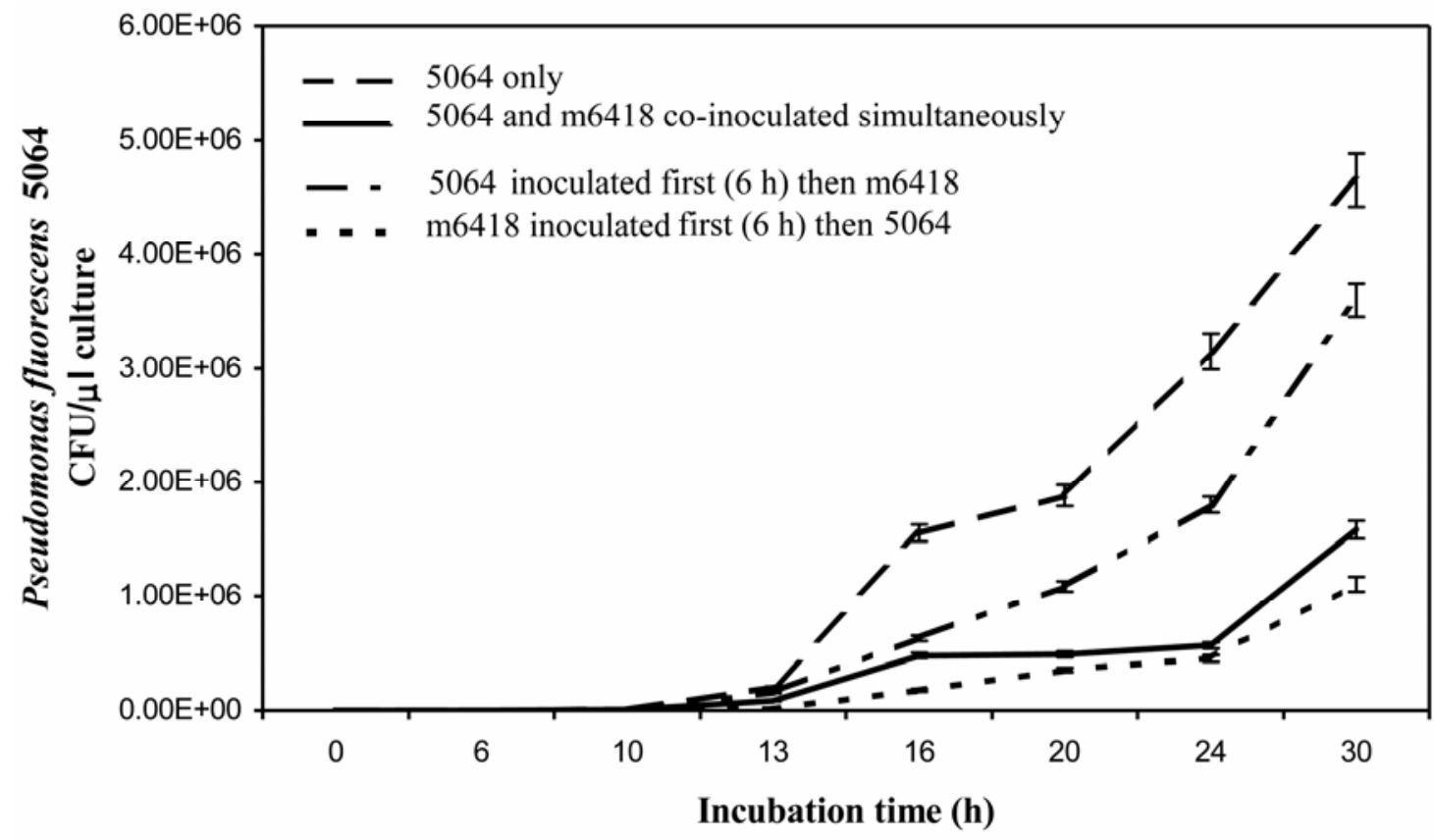

Fig. 4. Effects of Pseudomonas fluorescens $\mathrm{m} 6418$ on P. fluorescens 5064 population dynamics in liquid culture. Bars $=$ standard error of the mean.

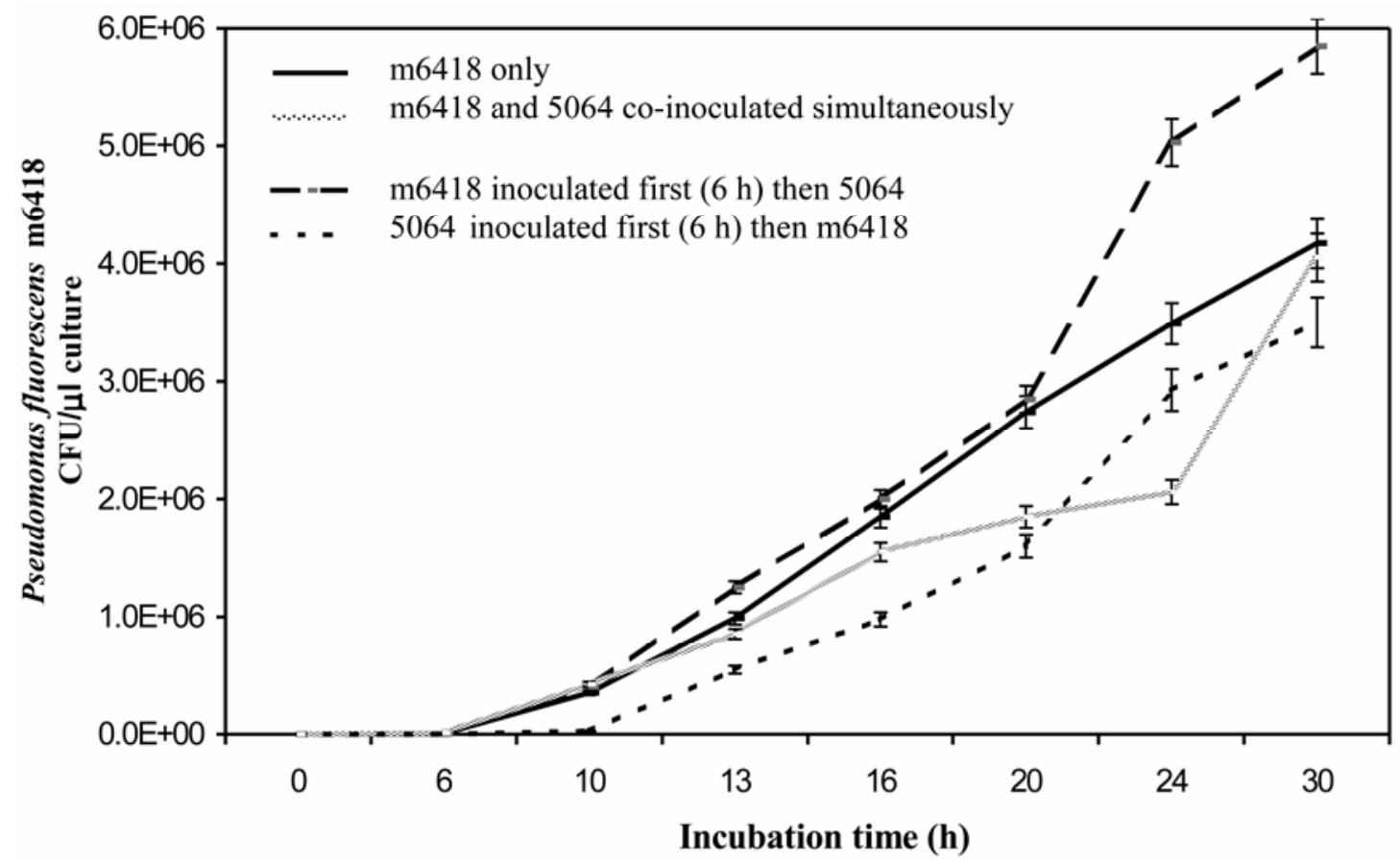

Fig. 5. Effects of Pseudomonas fluorescens 5064 on P. fluorescens m6418 population dynamics in liquid culture. Bars $=$ standard error of the mean. 


\section{DISCUSSION}

In this study, we examined the potential for the biological control of broccoli head rot, caused by GpIV P. fluorescens strains, with two bacterial isolates: a Tn5 mutant derived from the pathogen, P. fluorescens m6418, and Bacillus sp. A24. We have shown that the two biocontrol isolates are inhibitory toward the pathogen in two different ways: strain m6418 produces large amounts of the antimicrobial substance Prn, and Bacillus sp. A24 is capable of degrading the 3-hydroxyoctanoyl homoserine lactone produced by the pathogen. P. fluorescens m6418 was able to reduce head rot in an excised broccoli head bioassay by $41 \%$; Bacillus sp. A24 was less effective at $26 \%$.

Prn has been reported to suppress a wide range of fungal and bacterial pathogens either in agar bioassay or tissue pathogenicity tests, such as Rhizoctonia solani (8), Botrytis cinerea $(29,30)$,
Penicillium expansum (29), Pyrenophora tritici-repentis (41), Mycobacterium tuberculosis (14), and Fusarium sambucinum (4). EI-Banna and Winkelmann (18) tested the antimicrobial effect of Prn on almost 40 bacterial and fungal strains. In their study, Prn was active against several filamentous fungi including Pythium ultimum, yeasts, and gram-positive bacteria (including some Streptomyces species, especially $S$. antibioticus). However, almost all gram-negative bacteria tested, including E. coli $\mathrm{K} 12$ and P. fluorescens ATCC 13525, were resistant to the doses tested except for Proteus vulgaris ATCC 13315. Levenfors and colleagues (36) provided data demonstrating that Prn gave an inhibitory effect against Pythium ultimum when applied at a high concentration (50 mg/liter). However, Howell and Stipanovic (27) concluded that Prn was ineffective against Pythium ultimum. Pythium ultimum is a widespread and important oomycete plant pathogen causing seed decay, pre- and postemergence damping off, and

- - 5064 inoculated alone

- 5064 inoculated a day earlier than $\mathrm{m} 6418$

- - 5064 and m6418 co-inoculated simultaneously

5064 inoculated a day later than m6418

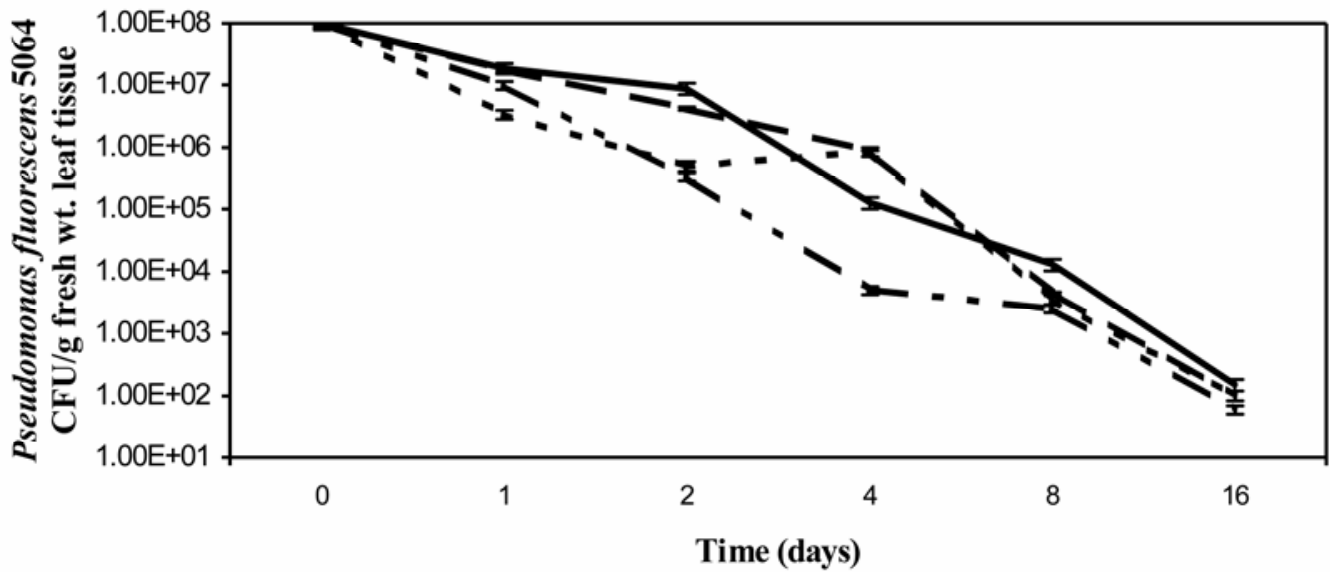

Fig. 6. Effects of Pseudomonas fluorescens $\mathrm{m} 6418$ on P. fluorescens 5064 population dynamics on broccoli leaves. Bars $=$ standard error of the mean.

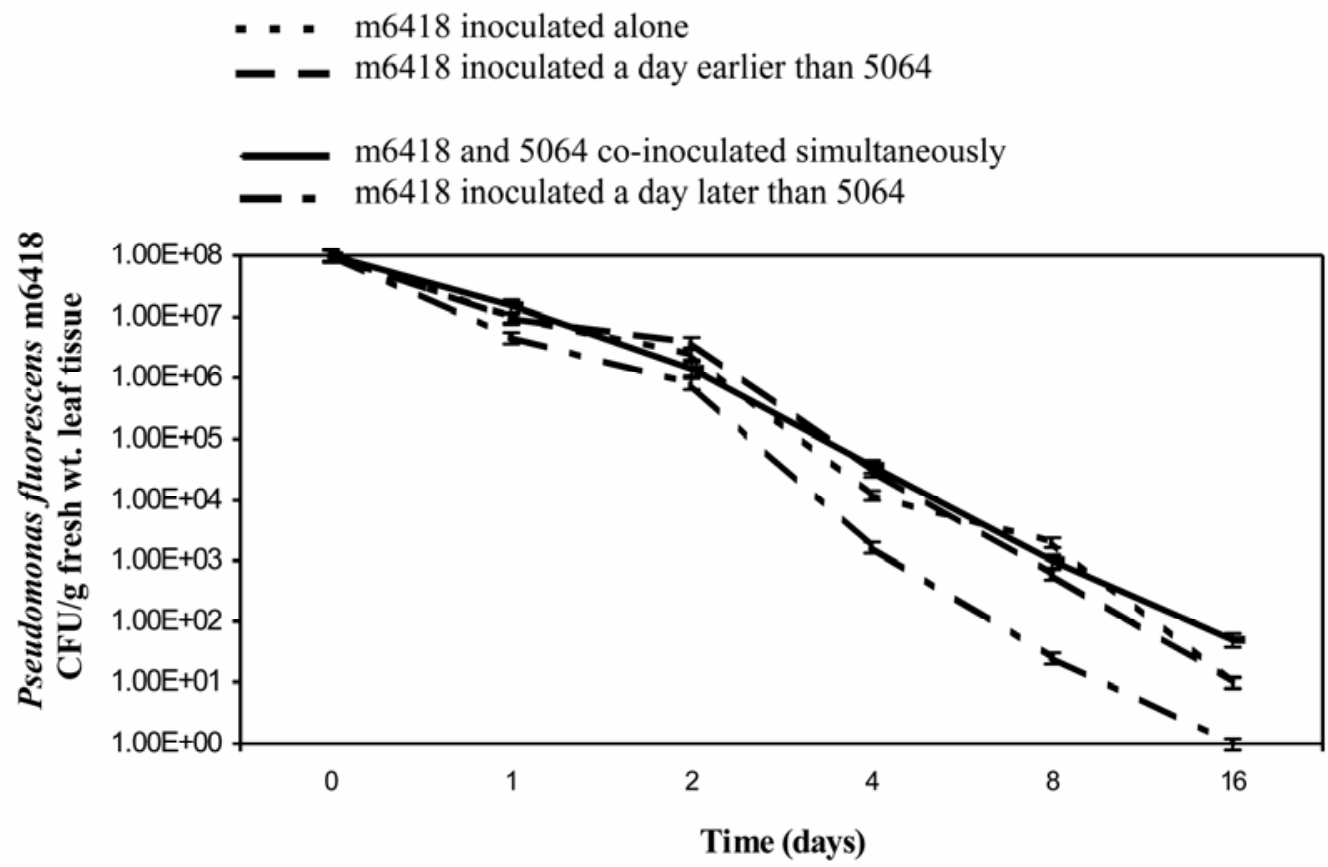

Fig. 7. Effects of Pseudomonas fluorescens 5064 on P. fluorescens $\mathrm{m} 6418$ population dynamics on broccoli leaves. Bars $=$ standard error of the mean. 
root rot in many plant species (24). In our study, Prn produced by strain m6418 had strong antibiotic activity against Pythium ultimum, as well as wild-type $P$. fluorescens 5064 and E. coli JM109 (data for the latter two not shown). The inhibitory effects shown by Prn toward Pythium ultimum in our study might partly be due to the high concentration of Prn produced by strain m6418.

Because Prn production is an important mechanism of biological control against fungal plant pathogens, extensive work has been carried out to elucidate its gene expression and regulation. In addition to the identification of the Prn synthesis gene operon (containing four genes) (22,33), Prn has also been reported to be under global genetic control by a two-component regulatory system composed of the sensor protein ApdA (also called LemA) (9) and the response regulator GacA (21,34). A mutation in apdA or gacA of $P$. fluorescens abolishes the production of Prn $(9,34)$. A sigma factor encoded by ropS is also reported to be necessary for Prn production $(41,43)$. In our study, the overexpression of Prn in the Tn5 mutant 6418 implies that the gene disrupted by $\operatorname{Tn} 5$ is a repressor within the Prn biosynthesis or regulation pathway.

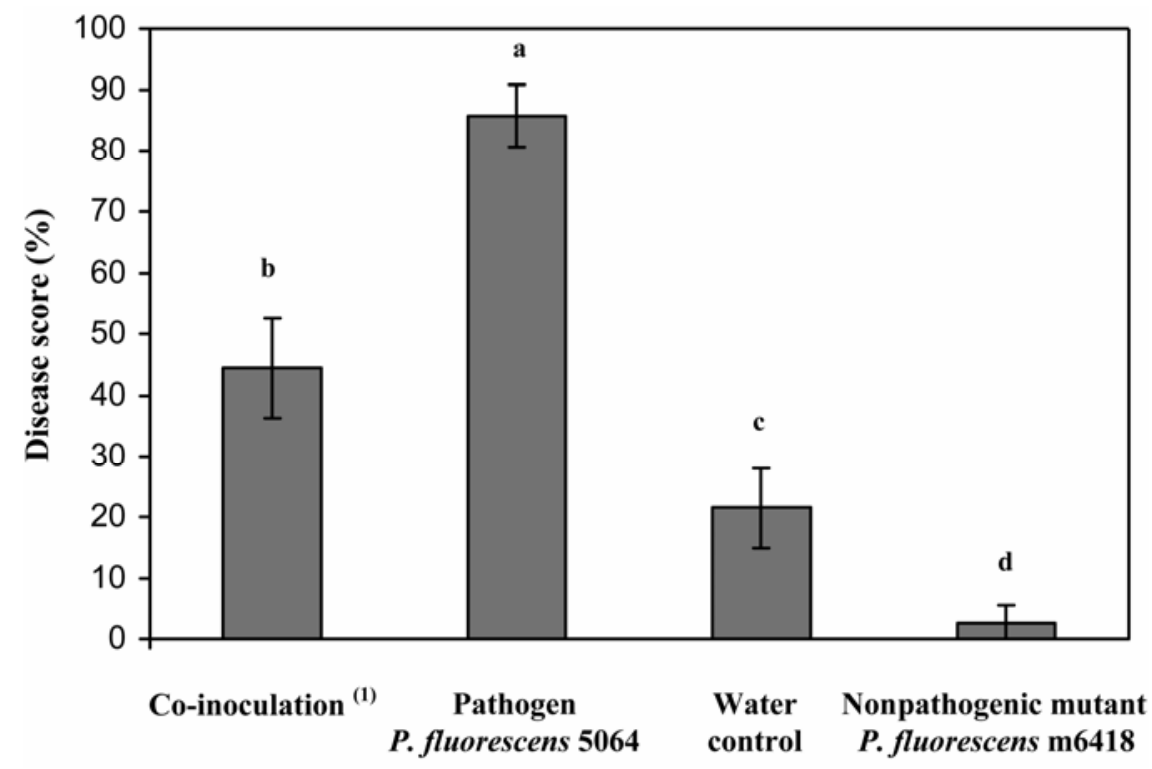

Fig. 8. Biological control of head rot on excised broccoli heads using nonpathogenic Pseudomonas fluorescens mutant m6418. The pathogen (P. fluorescens 5064) and nonpathogenic mutant (P. fluorescens m6418) were simultaneously co-inoculated on broccoli heads in a $1: 1$ ratio $\left(\right.$ each at $\left.1 \times 10^{8} \mathrm{CFU} / \mathrm{ml}\right)$. $0 \%=$ no disease symptoms; $100 \%=$ severe head rot. A five point scoring scale was used to assess the severity of disease symptoms: $0=$ no symptoms, $1=$ water soaking (loss of waxy bloom from florets), $2=$ water soaking and tissue browning but no rot, $3=$ tissue browning and softening (with rot), and $4=$ extensive black soft rot. Data were subjected to percentile angular transformation using arcsine before analysis; thus, the above categories 0 to 4 became $0(=0), 33(=1), 50(=2), 67(=3)$, and $100 \%(=4)$, respectively. Bars $=$ standard error of the mean. Different letters indicate treatments that were significantly different based on Fisher's protected least significant difference test, $P<0.05$.

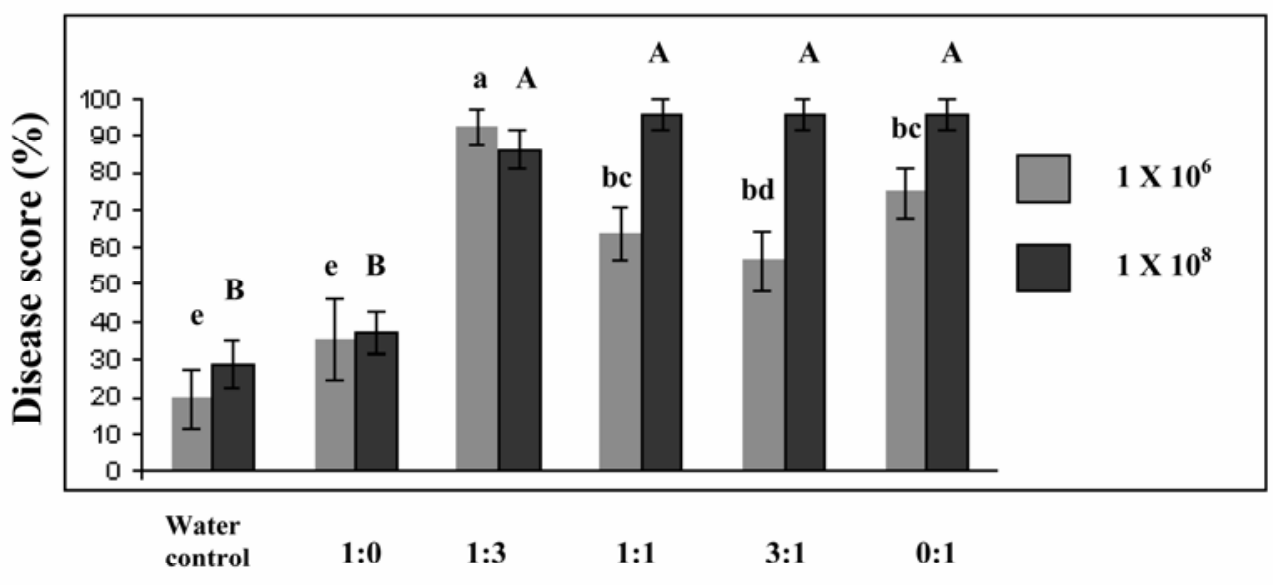

\section{Inoculum ratio of Bacillus sp. A24 : P. fluorescens 5064 (with final bacterial concentration of $1 \times 10^{6}$ and $1 \times 10^{8}$ )}

Fig. 9. Biological control of head rot on excised broccoli heads using Bacillus sp. A24. The pathogen (Pseudomonas fluorescens 5064) and biocontrol agent (Bacillus sp. A24) were simultaneously co-inoculated on broccoli heads in a 1:1 ratio in two separate experiments: (i) each at a concentration of $1 \times 10^{6} \mathrm{CFU} / \mathrm{ml}$, and (ii) each at a concentration of $1 \times 10^{8} \mathrm{CFU} / \mathrm{ml} .0 \%=$ no disease symptoms; $100 \%=$ severe head rot. A five point scoring scale was used to assess the severity of disease symptoms: $0=$ no symptoms, $1=$ water soaking (loss of waxy bloom from florets), 2 = water soaking and tissue browning but no rot, $3=$ tissue browning and softening (with rot), and $4=$ extensive black soft rot. Data were subjected to percentile angular transformation using arcsine before analysis; thus, the above categories 0 to 4 became $0(=0), 33(=1), 50(=2), 67(=3)$, and 100\% $(=4)$, respectively. Bars = standard error of the mean. Different letters when compared within each data set (i.e., when comparing treatments within either $1 \times 10^{6} \mathrm{CFU} / \mathrm{ml}$ or $1 \times 10^{8} \mathrm{CFU} / \mathrm{ml}$ ) indicate treatments that were significantly different based on Fisher's protected least significant difference test, $P<0.05$. 
The research conducted in this study has provided evidence that the antibiotic-producing strain m6418 could be used as a biocontrol agent to control broccoli head rot disease. Strain m6418 had significant inhibitory effects against $P$. fluorescens 5064 in culture, on broccoli seedlings, and excised broccoli heads. In culture, the inhibitory effect of strain m6418 was greater when it was inoculated and allowed to establish before P. fluorescens 5064, although this was not the case on broccoli leaves, possibly because of its lower fitness on leaves.

With Bacillus sp. A24, no disease control effect was observed at the higher pathogen inoculum concentration of $1 \times 10^{8} \mathrm{CFU} / \mathrm{ml}$. However, at a pathogen inoculum concentration of $1 \times 10^{6} \mathrm{CFU} / \mathrm{ml}$, Bacillus sp. A24 did suppress head rot. The lower effectiveness of Bacillus sp. A24 as a biocontrol agent might be due to the following reasons. (i) A level of $1 \times 10^{8} \mathrm{CFU} / \mathrm{ml}$ for the pathogen is very high and represents a severe test for a biocontrol agent. In natural infections, disease symptoms are initiated at levels of $10^{5}$ to $10^{6}$ cells of $P$. fluorescens on the head (data not shown). (ii) As we mentioned before, when $P$. fluorescens 5064 reaches a threshold population, its quorum sensing system will be activated and its virulence factors start to be expressed. Therefore, it will not make much difference for Bacillus sp. A24 to degrade the AHL of $P$. fluorescens after the quorum sensing system has already been triggered and the virulence factors have been expressed. Bacillus sp. A24 might have a better disease control effect in the natural environment, where $P$. fluorescens concentrations are less than we created in the laboratory tests (3). The prospective disease control effect of Bacillus depends on its ability to degrade the QSS and therefore block biosurfactant production, one of the pathogen's virulence factors (controlled by quorum sensing). However, subsequent assays showed that Bacillus sp. A24 itself is a biosurfactant producer (data not shown). Given the role of biosurfactant in broccoli head rot (26), it is possible that the biosurfactant produced by Bacillus sp. A24 enhanced disease, either by direct damage to the head surface and/or by encouraging damage by pathogenic $P$. fluorescens.

\section{ACKNOWLEDGMENTS}

We thank the Sino-British Fellowship Trust for funding this research as part of a Ph.D. studentship. We also wish to acknowledge funding from the Scottish Executive Environment and Rural Affairs Department (SEERAD). We thank P. Williams, University of Nottingham, for providing biosensor strains and G. Defago (ETH, Zurich, Switzerland) for the AHL-degrading strain Bacillus sp. A24.

\section{LITERATURE CITED}

1. Arima, K., Imanaka, H., Kousaka, M., Fukuta, A., and Tameera, G. 1965. Studies on pyrrolnitrin, a new antibiotic. I. Isolation and properties of pyrrolnitrin. J. Antibiot. 18:201-204.

2. Baker, C. J., Stavely, J. R., Thamas, C. A., Sasser, M., and MacFall, J. S. 1983. Inhibitory effect of Bacillus subtilis on Vromyces phaseoli and on development of rust pustules on bean leaves. Phytopathology 73:11481152.

3. Brokenshire, T., and Robertson, N. H. 1986. Control of calabrese spear rot with copper fungicides. Test of agrochemicals and cultivars No. 7. Ann. Appl. Biol. 108(suppl.):52-53.

4. Burkhead, K. D., Schisler, D. A., and Patricia, J. S. 1994. Pyrrolnitrin production by biological control agent Pseudomonas cepacia $\mathrm{B} 37 \mathrm{w}$ in culture and in colonized wounds of potatoes. Appl. Environ. Microbiol. 60:2031-2039.

5. Burr, T. J., Schroth, N., and Suslow, T. V. 1978. Increased potato yields by treatment of seed pieces with specific strains of Pseudomonas fluorescens and $P$. putida. Phytopathology 68:1377-1383.

6. Canaday, C. H., Mullins, C. A., Wyatt, J. E., Coffey, D. L., Mullins, J. A., and Hall, T. 1987. Bacterial soft rot of broccoli in Tennessee. Phytopathology 77:1712.

7. Canaday, C. H., Wyatt, J. E., and Mullins, C. A. 1991. Resistance in broccoli to bacterial soft rot caused by Pseudomonas marginalis and fluorescent Pseudomonas species. Plant Dis. 75:715-720.

8. Cartwright, D. K., Chilton, W. S., and Benson, D. M. 1995. Pyrrolnitrin and phenazine production by Pseudomonas cepacia, strain $5.5 \mathrm{~B}$, a biocontrol agent of Rhizoctonia solani. Appl. Microbiol. Biotechnol. 43:211216.

9. Corbell, N., and Loper, J. E. 1995. A global regulator of secondary metabolite production in Pseudomonas fluorescens Pf-5. J. Bacteriol. 177:6230-6236.

10. Cui, X., and Harling, R. 2005. N-Acyl-homoserine lactone-mediated quorum sensing blockage, a novel strategy for attenuating pathogenicity of gram-negative bacterial plant pathogens. Eur. J. Plant Pathol. 111:327339.

11. Cui, X., Harling, R., Mutch, P., and Darling, D. 2005. Identification of $N$ 3-hydroxyoctanoyl-homoserine lactone production in Pseudomonas fluorescens 5064, pathogenic to broccoli, and controlling biosurfactant production by quorum sensing. Eur. J. Plant Pathol. 111:297-308.

12. Darling, D. 1998. Bacterial head rot of broccoli: Pathogenicity and host susceptibility. Ph.D. diss. University of Edinburgh, Scotland, UK.

13. Darling, D., Harling, R., Simpson, R. A., McRoberts, N., and Hunter, E. A. 2000. Susceptibility of broccoli cultivars to bacterial head rot: In vitro screening and the role of head morphology in resistance. Eur. J. Plant Pathol. 106:11-17.

14. Di Santo, R., Costi, R., Artico, M., Massa, S., Lampis, G., Deidda, D., and Pompei, R. 1998. Pyrrolnitrin and related pyrroles endowed with antibacterial activities against Mycobacterium tuberculosis. Bioorgan. Med. Chem. Lett. 8:2931-2936.

15. Dong, Y. H., Wang, L. H., Xu, J. L., Zhang, H. B., Zhang, X. F., and Zhang, L. H. 2001. Quenching quorum sensing dependent bacterial infection by an $N$-acyl homoserine lactonase. Nature 411:813-817.

16. Dong, Y. H., Xu, J. L., Li, X. Z., and Zhang, L. H. 2000. AiiA, an enzyme that inactivates the acyl-homoserine lactone quorum sensing signal and attenuates the virulence of Erwinia carotovora. Proc. Natl. Acad. Sci. USA 97:3526-3531.

17. Dong, Y. H., Zhang, X. F., Xu, J. L., and Zhang, L. H. 2004. Insecticidal Bacillus thuringiensis silences Erwinia carotovora virulence by a new form of microbial antagonism, signal interference. Appl. Environ. Microbiol. 70:954-960.

18. EI-Banna, L., and Winkelmann, G. 1998. Pyrrolnitrin from Burkholderia cepacia: Antibiotic activity against fungi and novel activities against streptomycetes. J. Appl. Microbiol. 85:69-78.

19. Finch, R. G., Pritchard, D. I., Bycroft, B. W., Williams, P., and Stewart, G. S. A. B. 1998. Quorum sensing - a novel target for anti-infective therapy. J. Antimicrobial. Chemoth. 42:569-571.

20. Fuqua, W. C., Winans, S. C., and Greenberg, E. P. 1994. Quorum sensing in bacteria; the LuxR-LuxI Family of cell density responsive transcriptional regulators. J. Bacteriol. 176:269-275.

21. Gaffney, T. D., Lam, S. T., Ligon, J., Gates, K., Frazelle, A., Di Maio, J., Hill, S., Goodwin, S., Torkewitz, N., Allshouse, A. M., Kempf, H. J., and Becker, J. O. 1994. Global regulation of expression of anti-fungal factors by a Pseudomonas fluorescens biological control strain. Mol. PlantMicrobe Interact. 7:455-463.

22. Hammer, P. E., Hill, D. S., Lam, S. T., van Pee, K. H., and Ligon, J. M. 1997. Four genes from Pseudomonas fluorescens that encode the biosynthesis of pyrrolnitrin. Appl. Environ. Microbiol. 63:2147-2154.

23. Harling, R., and Sutton, M. 2002. Spear rot of Calabrese. Factsheet 13/02, Horticultural Development Council, East Malling, Kent, UK.

24. Hendrix, F., Jr., and Campbell, W. A. 1973. Pythium as plant pathogens. Annu. Rev. Phytopathol. 11:77-98.

25. Hildebrand, P. D. 1986. Symptomatology and etiology of head rot of broccoli in Atlantic Canada. Can. J. Plant Pathol. 8:350.

26. Hildebrand, P. D. 1989. Surfactant-like characteristics and identity of bacteria associated with broccoli head rot in Atlantic Canada. Can. J. Plant Pathol. 11:205-224.

27. Howell, C. R., and Stipanovic, R. D. 1979. Control of Rhizoctonia solani on cotton seedlings with Pseudomonas fluorescens and with an antibiotic produced by the bacterium. Phytopathology 69:480-482.

28. Howell, C. R., and Stipanovic, R. D. 1980. Suppression of Pythium ultimum-induced damping-off of cotton seedlings by Pseudomonas fluorescens and its antibiotic, pyoluteorin. Phytopathology 70:712-715.

29. Janisiewicz, W., Yourman, L., Roitman, J., and Mahoney, N. 1991. Postharvest control of blue mold and gray mold of apples and pears by dip treatment with pyrrolnitrin, a metabolite of Pseudomonas cepacia. Plant Dis. 75:490-494.

30. Kamensky, M., Ovadis, M., Chet, I., and Chernin, L. 2003. Soil-borne strain IC 14 of Serratia plymuthica with multiple mechanisms of antifungal activity provides biocontrol of Botrytis cinerea and Sclerotinia sclerotiorum disease. Soil Biol. Biochem. 35:323-331.

31. Keel, C., Schnider, U., Maurhofer, M., Voisard, C., Laville, J., Burger, F., Withner, P., Haas, D., and DeFago, G. 1992. Suppression of root diseases by Pseudomonas fluorescens CHA0: Importance of the bacterial secondary metabolite 2,4-diacetylphloroglucinol. Mol. Plant-Microbe Interact. 5:4-13. 
32. Khan, N. I., Schisler, D. A., Boehm, M. J., Slininger, P. J., and McCormick, S. P. 1999. Performance of selected antagonists of Fusarium head blight against a range of Gibberella zeae isolates. (Abstr.) Phytopathology 89(suppl.):S39.

33. Kirner, S., Hammer, P. E., Hill, D. S., Altmann, A., Fischer, I., Weislo, L. J., Lanahan, M., van Pee, K. H., and Ligon, J. M. 1998. Functions encoded by pyrrolnitrin biosynthetic genes from Pseudomonas fluorescens. J. Bacteriol. 180:1939-1943.

34. Laville, J., Voisard, C., Keel, C., Maurhofer, M., Defago, G., and Haas, D. 1992. Global control in Pseudomonas fluorescens mediating antibiotic synthesis and suppression of black root rot of tobacco. Proc. Natl. Acad. Sci. USA 89:1562-1566.

35. Lee, S. J., Park, S. Y., Lee, J. J., Yum, D. Y., Koo, B. T., and Lee, J. K. 2002. Genes encoding the $N$-acyl homoserine lactone-degrading enzyme are widespread in many subspecies of Bacillus thuringiensis. Appl. Environ. Microbiol. 68:3919-3924.

36. Levenfors, J. J., Hedman, R., Thaning, C., Gerhardson, B., and Welch, C. J. 2004. Broad-spectrum antifungal metabolites produced by the soil bacterium Serratia plymuthica A 153. Soil Biol. Biochem. 36:677-685.

37. Liao, C. H., and Sapers, G. M. 1999. Influence of soft rot bacteria on growth of Listeria monocytogenes on potato tuber slices. J. Food Prot. 62:343-348.

38. Ludy, R. L., Hemphill, D. D., and Powelson, M. L. 1989. Sprinkler irrigation effect on head rot (Erwinia carotovora subsp. carotovora) and yield of broccoli. Phytopathology 79:910.

39. Mahoney, N. E., and Roitman, J. N. 1990. High-performance liquid chromatographic analysis of phenylpyrroles produced by Pseudomonas cepacia. J. Chromatogr. 508:247-251.

40. Nowak-Thompsan, B., Gould, S. J., Kraus, J., and Loper, J. E. 1994. Production of 2,4-diacetylphloroglucinol by the biocontrol agent Pseudomonas fluorescens Pf-5. Can. J. Microbiol. 40:1064-1066.

41. Pfender, W. F., Kraus, J., and Loper, J. E. 1993. A genomic region from Pseudomonas fluorescens Pf-5 required for pyrrolnitrin production and inhibition of Pyrenophora tritici-repentis in wheat straw. Phytopathology 83:1223-1228.

42. Robertson, S., Brokenshire, T., Kellock, L. J., Sutton, M., Chard, J., and Harling, R. 1993. Bacterial spear (head) rot of calabrese in Scotland: Causal organisms, cultivar susceptibility and disease control. Proc. Crop Prot. Northern Britain 1993:265-270.

43. Sarniguet, A., Kraus, J., Henkels, M. D., Muehlchen, A. M., and Loper, J. E. 1995. The sigma factor sigma affects antibiotic production and biological control activity of Pseudomonas fluorescens Pf-5. Proc. Natl. Acad. Sci. USA 92:12255-12259.

44. Schefler, W. C. 1969. Statistics for the Biological Sciences. AddisonWesley Professional, Boston, MA.

45. Schisler, D. A., Khan, N. I., and Boehm, M. J. 2002. Biological control of Fusarium head blight of wheat and deoxynivalenol levels in grain via use of microbial antagonists. Adv. Exp. Med. Biol. 504:53-69.

46. Schroth, M. N., and Hancock, J. G. 1983. Disease suppressive soil and root colonizing bacteria. Science 216:1376-1382.

47. Scott, J. E., Hughes, E. W., and Shuttleworth, A. 1981. A collagenassociated Ehrlich chromogen-a pyrrolic cross-link. Biosci. Rep. 1:611618.

48. Shanahan, P., O'Sullian, D. J., Simpson, P., Glennon, J. D., and O'Gara, F. 1992. Isolation of 2,4-diacetylphloroglucinol from a fluorescent pseudomonad and investigation of physiological parameters influencing its production. Appl. Environ. Microbiol. 58:353-358.

49. Thomashow, L. S., and Weller, D. M. 1992. Role of phenazine antibiotic from Pseudomonas fluorescens in biological control of Gaeumannomyces graminis var. tritici. J. Bacteriol. 170:3499-3508.

50. Weller, D. M., and Cook, R. J. 1983. Suppression of take-all of wheat by seed treatments with fluorescent pseudomonads. Phytopathology 73:463469.

51. Wimalajeewa, D. L. S., Hallam, N. D., Hayward, A. D., and Price, T. V. 1987. The etiology of head rot disease of broccoli. Aust. J. Agric. Res. 38:735-742. 